\title{
PENGARUH MODEL $C O-O P$ CO-OP MANDIRI TERHADAP KEMAMPUAN PEMECAHAN MASALAH DITINJAU DARI GAYA BELAJAR SISWA
}

\author{
Henri $^{1}$, Syamsurizal ${ }^{2}$, Syaiful ${ }^{3}$ \\ 1,2,3 Magister Pendidikan Matematika, Universitas Jambi \\ E-mail: henrisamuel282@gmail.com ${ }^{l)}$
}

Received 20 October 2018; Received in revised form 13 December 2018; Accepted 23 December 2018

\begin{abstract}
This experimental quasi is aimed to know the influence of Co-op Co-op model independently on problem solving abilities in terms of student learning style. This research method is a quasy experiment with quantitative approach. The subjects of the study were the students of class X IPS 3 and Class X IPS 4. Subject take technique done by purposive sampling. Experimental class using the Co-op-self-Co-op learning model and control class using the conventional Co-op Co-op of learning model. Data were collected using written test techniques to obtain data on problem solving abilities and student learning styles. The techniques of analysis data in testing hypothesis used two away Anova, followed by Tukey test. The results of this study obtained the average value of experimental class 1 taught with Co-op self-Co-op learning model is 65.56, the average experiment class 2 is 66.33 and the average control class that is taught by the model of learning Co-op conventional Co-op is 59.83. Based on the result of the research, it can be concluded that (1) There is influence of independent Co-op Co-op model and learning style to problem solving ability, (2) Co-op Co-op model independent of problem solving ability, (3) learning styles on problem-solving skills and (4) there is an interaction between Co-op Co-op models and learning styles in influencing problem-solving abilities.
\end{abstract}

Keywords: Co-op Co-op learning model; learning style; problem-solving ability.

\section{PENDAHULUAN}

Hakikat pembelajaran matematika meliputi dimensi proses, dimensi pengetahuan, nilai atau sikap. Matematika sering dipandang sebagai mata pelajaran yang kurang diminati atau kalau bisa dihindari. Hal ini dikarenakan matematika merupakan ilmu pasti, yang selalu berhubungan dengan angka yang dianggap rumit. Berdasarkan hasil observasi dan wawancara, didapat beberapa alasan siswa tidak serius dalam pembelajaran matematika, di antaranya siswa menganggap matematika adalah mata pelajaran yang sulit dipahami.

Beberapa penelitian tentang model pembelajaran kooperatif tipe $\mathrm{Co}$ op Co-op yan telah dilakukan menurut Mahuda (2017) mengatakan bahwa model kooperatif tipe Co-op Co-op dengan Pendekatan open-ended mampu meningkatkan pemecahan masalah matematis siswa SMA. Model kooperatif tipe Co-op Co-op juga menjadi inovasi agar siswa lebih aktif lagi belajar. Ferinaldi (2013) mengatakan bahwa model pembelajaran Co-op Co-op berpengaruh terhadap pemecahan masalah dan penalaran matematis mahasiswa. Selanjutnya Dewi (2013) mengatakan bahwa penerapan model cooperative tipe $\mathrm{Co}$ op Co-op disertai metode eksperimen mampu meningkatkan aktifitas siswa saat proses pembelajaran berlangsung dan mampu meningkatkan hasil belajar siswa.

Hal serupa juga dikatakan Thamimi dan Kusnoto (2017) bahwa metode pembelajaran kooperatif model Co-op Co-op mampu memberikan motivasi kepada siswa untuk belajar sehingga mampu meningkatkan prestasi belajar siswa dalam pembelajaran. Sejalan dengan Kurniawan dkk (2015)

\section{2 | AKSIOMA}


mengatakan bahwa Eksperimentasi Model Pembelajaran Co-op Co-op, Discovey Learning dan Problem Based Dengan Pendekatan Saintifik Siswa Kelas VIII SMP Negeri Sekabupaten Ngawi Pada Materi Bangun Ruang Sisi Datar mampu meningkatkan Kreativitas Belajar Matematika siswa.

Berdasarkan observasi, guru belum sepenuhnya bisa mensiasati siswa untuk belajar aktif dan menyenangkan sehingga proses pembelajaran banyak didominasi oleh guru seperti menggunakan metode ceramah, tanya jawab, memberikan latihan, membekali siswa dengan pekerjaan rumah. Selain itu, guru kurang melibatkan siswa dalam proses belajar mengajar sehingga kesempatan siswa untuk belajar sesuai dengan gaya belajarnya kurang terjembatani. Menurut Deporter dan Hernacki (2010:110) mengatakan gaya belajar merupakan kunci untuk mengembangkan kinerja dalam pekerjaan, sekolah, dan dalam situasisituasi antar pribadi.

Selain melakukan observasi terhadap gaya belajar dan mewawancarai siswa, juga mengobservasi cara guru mengajar dan mewawancarai guru pada tanggal 2 dan 3 September 2017 diperoleh informasi bahwa masih ada siswa yang memperoleh nilai di bawah kriteria ketuntasan minimum (KKM). Hal ini dikarenakan kemampuan pemahaman materi yang dimiliki peserta didik masih tergolong rendah, beberapa kemampuan yang dimaksud yaitu masih kurangnya kemampuan siswa dalam memecahkan masalah.

Keadaan yang demikian menyebabkan kelas tidak kondusif, karena hanya beberapa peserta didik yang aktif dalam bertanya sedangkan peserta didik yang lainnya kebanyakan ribut dan mengganggu teman.
Permasalahan lain yang muncul pada peserta didik yaitu kurangnya kemampuan siswa dalam memecahkan. Masalah dalam proses pembelajaran biasanya ditunjukkan dengan perilaku malas belajar dan kurang memperhatikan penjelasan guru.

Disamping

kurangnya

kemampuan siswa dalam memecahkan masalah, terdapat aspek lain seperti guru masih menggunakan model pembelajaran konvensional yaitu pengajaran berpusat pada guru dengan metode ceramah yang disertai tanya jawab dengan peserta didik. Pada pelaksanaannya siswa cenderung pasif dan hanya duduk dan mendengarkan apa yang dikatakan guru (teacher center) sehingga berpengaruh terhadap kemampuan siswa dalam memecahkan masalah.

Permasalahan di atas merupakan kondisi yang harus menjadi perhatian sungguh-sungguh bagi guru. Oleh karena itu, diperlukan suatu usaha untuk menciptakan kondisi pembelajaran agar mampu meningkatkan kemampuan pemecahan masalah siswa dengan memperhatikan gaya belajar dari siswa agar hasil belajar yang diperoleh lebih optimal.

Slavin (2005) mengakatakan Coop Co-op merupakan model pembelajaran kooperatif yang berorientasi pada tugas pembelajaran dan peserta didik mengendalikan apa dan bagaimana mempelajari bahan yang ditugaskan kepada mereka.Model pembelajaran Co-op Co-op melatih siswa untuk bertanggung jawab dan bekerja keras menyelesaikan topik kecil yang dipercayakan oleh tim, setelah itu memaparkan dan mendiskusikan dalam kelompok kecil. Hal ini dapat membuat siswa lebih kreatif dalam mengeluarkan ide-ide, saling berbagi pengalaman dan bekerja sama dalam kelompok kecil untuk pemecahan topik kecil, kemudian 
mendiskusikan dalam satu tim untuk menggali lebih topik yang telah dipilih dan memaparkan di kelas dalam bentuk presentasi dan diskusi. Penerapan model pembelajaran Co-op Co-op dapat meningkatkan kemampuan pemecahan masalah matematika agar lebih baik. Langkah- langkah pembelajaran dengan model Co-op Co-op menurut Slavin (2005:229-236) adalah (1) Diskusi kelas yang terpusat pada siswa, (2) Seleksi dan pembentukan kelompok, (3) Seleksi topik kelompok, (4) Seleksi topik kecil, (5) Persiapan topik kecil, (6) Presentasi kelompok kecil, (7) Persiapan presentasi kelompok, (8) Presentasi kelompok, (9) Evaluasi.

Berdasarkan permasalahan yang dikemukakan maka batasan masalah dalam penelitian ini adalah kemampuan pemecahan masalah siswa masih rendah pada mata pelajaran Matematika. Pada penelitian ini juga akan ditinjau pengaruh gaya belajar siswa terhadap kemampuan pemecahan masalah siswa.

Gaya belajar merupakan cara yang sfatnya individu untuk memperoleh dan menyerap informasi dari lingkungannya, termasuk lingkungan belajar (Nur \& Rini, 2013:11). Gaya belajar adalah gaya yang konsisten yang dilakukan oleh seorang murid dalam menangkap stimulus atau informasi, cara mengingat berfikir dan memecahkan soal. Gaya belajar merupakan cara yang lebih disukai oleh peserta didik dalam suatu proses pembelajaran. Dengan gaya belajar, peserta didik akan lebih mudah memahami pelajaran. Sebagian peserta didik lebih suka pendidik mereka mengajar dengan cara menulis pelajaran di papan tulis lalu memahaminya.

Kemampuan pemecahan masalah merupakan hasil utama dari suatu proses pembelajaran. Yusuf (2014) mengatakan masalah merupakan bagian dari kehidupan manusia baik bersumber dari dalam diri maupun lingkungan sekitar. . Hampir setiap hari manusia berhadapan dengan suatu masalah yang perlu dicari jalan keluarnya. Dimyati (2013) mengatakan bahwa tugas pendidik harus menemukan masalahmasalah yang dialami siswa.

Menurut Beberapa indikator kemempuan pemecahan masalah matematika menurut NCTM (2000) sebagai berikut: (1) Mengidentifikasi unsur-unsur yang diketahui, yang dinyatakan, dan kecukupan unsur yang diperlukan, (2) Merumuskan masalah matematik atau menyusun model matematika, (3) Menerapkan strategi untuk menyelesaikan berbagai masalah (sejenis dan masalah baru) dalam atau luar matematika, (4) Menjelaskan atau menginterprestasi hasil sesuai permasalahan asal, (5) Menggunakan matematika secara bermakna.

Namun model pembelajaran $\mathrm{Co}$ op Co-op memiliki kelemahan seperti yang diungkapkan slavin (2005) mengatakan bahwa model pembelajaran Co-op Co-op memiliki kelemahan yaitu membutuhkan banyak waktu untuk mempersiapkan materi kecil, berdiskusi, dan mempersentasikan hasil diskusi kelompok sehingga dibutuhkan pengetahuan waktu yang lebih efektif dan efesien.

Atas dasar untuk menutupi kelemahan tersebut peneliti melakukan modifiksi terhadap model pembelajaran Co-op Co-op konvensional yaitu peneliti berupaya menutupi kelemahan tersebut dengan memangkas langkahlangkah dalam pembelajaran Co-op Coop untuk dilakukan dirumah atau diluar jam pelajaran. Dalam model Co-op Coop mandiri siswa tidak lagi melakukan persiapan materi kecil untuk didiskusikan dikelas karena siswa sudah melakukannya dirumah, dengan demikian siswa dituntut lebih mandiri 
dan bertanggung jawab atas tugas yang diberikan kepadanya.

Dalam model pembelajaran Co-op Co-op mandiri siswa dituntut agar bisa menyelesaikan masalah masalah dengan mandiri diluar jam pelajaran matematika, siswa dituntut agar dapat bertanggung jawab baik secara individu dan kelompok dalam mengerjakan tugas yang diberikan. Kelebihan dari model pembelajaran Co-op Co-op mandiri adalah siswa lebih memiliki banyak waktu untuk mempersiapkan materi kecil dan mendiskusikannya, selain itu juga siswa lebih memiliki banyak sumber yang dapat dimamfaatkan dibandingkan dengan model pembelajaran Co-op Co-op konvensional.

Berdasarkan permasalahan yang dikemukakan maka batasan masalah dalam penelitian ini adalah kemampuan pemecahan masalah siswa masih rendah pada mata pelajaran Matematika. Pada penelitian ini juga akan ditinjau pengaruh gaya belajar siswa terhadap kemampuan pemecahan masalah siswa.

Gaya belajar merupakan cara yang sfatnya individu untuk memperoleh dan menyerap informasi dari lingkungannya, termasuk lingkungan belajar (Nur \& Rini, 2013:11). Gaya belajar adalah gaya yang konsisten yang dilakukan oleh seorang murid dalam menangkap stimulus atau informasi, cara mengingat berfikir dan memecahkan soal. Gaya belajar merupakan cara yang lebih disukai oleh peserta didik dalam suatu proses pembelajaran. Dengan gaya belajar, peserta didik akan lebih mudah memahami pelajaran. Sebagian peserta didik lebih suka pendidik mereka mengajar dengan cara menulis pelajaran di papan tulis lalu memahaminya.

Kemampuan pemecahan masalah merupakan hasil utama dari suatu proses pembelajaran. Yusuf (2014) mengatakan masalah merupakan bagian dari kehidupan manusia baik bersumber dari dalam diri maupun lingkungan sekitar. . Hampir setiap hari manusia berhadapan dengan suatu masalah yang perlu dicari jalan keluarnya. Dimyati (2013) mengatakan bahwa tugas pendidik harus menemukan masalahmasalah yang dialami siswa.

Menurut Beberapa indikator kemempuan pemecahan masalah matematika menurut NCTM (2000) sebagai berikut: (1) Mengidentifikasi unsur-unsur yang diketahui, yang dinyatakan, dan kecukupan unsur yang diperlukan, (2) Merumuskan masalah matematik atau menyusun model matematika, (3) Menerapkan strategi untuk menyelesaikan berbagai masalah (sejenis dan masalah baru) dalam atau luar matematika, (4) Menjelaskan atau menginterprestasi hasil sesuai permasalahan asal, (5) Menggunakan matematika secara bermakna.

Berdasarkan beberapa penjelasan di atas terlihat bahwa pentingnya pelaksanaan pembelajaran dengan model yang lebih bervariasi guna meningkatkan kemampuan siswa dalam memecahkan masalah, aktivitas, keaktifan, serta membentuk sikap. Oleh karena itu penulis tertarik untuk melakukan penelitian model pembelajaran koopratif tipe Co-op $\mathrm{Co}$ op dengan judul Pengaruh Model Pembelajaran Kooperatif Tipe Co-op Co-op Mandiri Terhadap Kemampuan Pemecahan Masalah Ditinjau Dari Gaya Belajar Siswa.

Penelitian ini bertujuan untuk mengetahui: (1) pengaruh model pembelajaran kooperatif tipe Co-op Coop mandiri dan gaya belajar terhadap kemampuan pemecahan masalah, (2) pengaruh pendekatan model pembelajaran kooperatif tipe Co-op Coop mandiri terhadap kemampuan pemecahan masalah, (3) pengaruh gaya 
belajar terhadap kemampuan pemecahan masalah, (4) interaksi antara model pembelajaran kooperatif tipe $\mathrm{Co}$ op Co-op mandiri dan gaya belajar dalam mempengaruhi kemampuan pemecahan masalah.

\section{METODE PENELITIAN}

Penelitian ini merupakan penelitian eksperimen (Sugiyono, 2010). Penelitian ini dilakukan terhadap dua kelas sampel dengan satu kelas diberikan perlakuan sebagai kelas eksperimen dan satu kelas diberikan perlakuan sebagai kelas kontrol. Kelas eksperimen diajarkan dengan model pembelajaran kooperatif tipe Co-op Coop mandiri, serta kelas kontrol diajarkan dengan model pembelajaran Co-op Co-op konvensional.

Variabel pada penelitian ini terdiri dari (1) variabel bebas yaitu model pembelajaran Co-op Co-op mandiri, (2) variabel terikat yaitu pemecahan masalah matematika dan (3) variabel moderator yaitu gaya belajar siswa. Desain penelitian yang digunakan adalah Randomized Control Group Only Design.

Rancangan penelitian yang digunakan dalam penelitian ini adalah rancangan faktorial $(2 \times 2)$. Perbedaan treatment pada kelas eksperimen dan kelas kontrol terletak pada penggunaan model pembelajaran yang berbeda. Pada kelas eksperimen digunakan model pembelajaran Co-op Co-op mandiri sedangkan pada kelas kontrol digunakan model pembelajaran Co-op Co-op konvensional. Adapun faktor pemilihannya adalah variabel moderator gaya belajar siswa. Pemilihannya dibagi atas dua tingkatan yaitu siswa yang memiliki gaya belajar field dependent dan field independent.

Teknik pemilihan subjek penelitian yang digunakan adalah teknik purposive sampling. Hasil penelitian tidak akan digeneralisasikan ke populasi karena pengambilan sampel tidak diambil secara random. Dalam penelitian ini akan diambil 3 kelas yang akan dijadikan sebagai subjek penelitian. Dalam penelitian ini yang akan menjadi subjek penelitian adalah siswa kelas X IPS 2, X IPS 3 dan X IPS 4.

Instrumen penelitian yang digunakan dalam penelitian ini adalah instrumen berupa soal tes. Tes yang digunakan berupa tes tertulis yang berbentuk uraian terdiri dari 10 soal yang telah divalidasi. Selanjutnya instrumen ini diberikan kepada siswa yang telah dipilih sebagai subjek penelitian. Data yang diperoleh dari instrumen selanjutnya dianalisis menurut tujuan penelitian. Sebelum instrumen digunakan sebagai alat pengumpulan data, terlebih dahulu instrumen diuji cobakan pada siswa yang bukan subjek penelitian dengan tujuan untuk mendapatkan soal yang baik, untuk itu dilakukan uji statistik berupa validitas, reliabelitas tes, daya beda dan indeks kesukaran.

Instrumen penelitian selanjutnya adalah group embeded figure test (GEFT) yang digunakan adalah group embeded figure test (GEFT) yang dikembangkan telah divalidasi ahli serta telah diujicoba sebelum digunakan dalam penelitian. group embeded figure test (GEFT) yang digunakan ini merupakan tes yang digunakan untuk melihat gaya belajar siswa.

Untuk mendapatkan kesimpulan dari hasil penelitian, maka perlu analisis data terhadap data yang diperoleh. Tujuan menganalisis data untuk untuk mendapatkan bukti apakah terdapat pengaruh model pembelajaran Co-op Co-op terhadap kemampuan pemecahan masalah ditinjau dari gaya belajar siswa. Sebelum melakukan analisis data, maka terlebih dahulu 
dilakukan. uji normalitas terhadap populasi dan uji homogenitas terhadap variabel penelitian.

Berdasarkan hipotesis penelitian, maka untuk menguji hipotesis tersebut digunakan analisis varians (ANAVA) dua arah dan uji Tukey. Karena data yang didapat berdistribusi normal dan bersifat homogen maka analisis data dapat dilakukan dengan menggunakan anava dua arah dan uji lanjut dengan menggunakan uji Tukey.

\section{HASIL PENELITIAN DAN PEMBAHASAN}

Hasil tes pemecahan masalah matematika siswa terdiri dari empat indikator yaitu Mengidentifikasi unsurunsur, Merumuskan masalah matematika, Menerapkan strategi untuk menyelesaikan berbagai masalah, Menjelaskan atau menginterpretasikan hasil dengan menggunakan matematika secara bermakna, telah diberikan kelas eksperimen 1, eksperimen 2, dan kelas kontrol. Berikut ini adalah data pemecahan masalah matematika siswa yang disajikan pada Tabel 1 .

Tabel 1. Tabel Pemecahan Masalah Matematika Siswa Kelas Eksperimen 1, Eksperimen 2, dan Kelas Kontrol

\begin{tabular}{|c|c|c|c|c|}
\hline \multirow[b]{2}{*}{ No } & \multirow[b]{2}{*}{ Statistik } & \multicolumn{3}{|c|}{ Model Pembelajaran } \\
\hline & & $\begin{array}{c}\text { Co-op Co-op } \\
\text { mandiri I }\end{array}$ & $\begin{array}{c}\text { Co-op Co-op } \\
\text { mandiri II }\end{array}$ & $\begin{array}{c}\text { Co-op Co-op } \\
\text { Konvensioanal }\end{array}$ \\
\hline 1. & Jumlah Sampel (N) & 30 & 30 & 30 \\
\hline 2. & Rata-rata (Mean) & 65,67 & 66,33 & 59,83 \\
\hline & Standar Error Mean & 1,761 & 1,541 & 2,094 \\
\hline & Median & 68,00 & 65,00 & 60,00 \\
\hline & Modus & 76 & 56 & 52 \\
\hline & Standar Deviasi & 9,643 & 8,438 & 11,471 \\
\hline 7. & Varians & 92,989 & 71,195 & 131,592 \\
\hline & Maksimum & 84 & 84 & 78 \\
\hline & Minimum & 50 & 54 & 40 \\
\hline 10. & Range & 34 & 30 & 38 \\
\hline \multicolumn{3}{|c|}{ Selanjutnya untuk melihat } & \multirow{3}{*}{\multicolumn{2}{|c|}{$\begin{array}{l}\text { siswa (independen dan dependen) } \\
\text { terhadap hasil belajar matematika siswa, } \\
\text { terlihat bahwa nilai } \mathrm{F}_{\text {hitung adalah }} \\
\text { 40,953. Nilai } \mathrm{F}_{\text {tabel adalah } 3,10 \text {. Jika }} \\
\text { dibandingkan dengan } \mathrm{F}_{\text {hitung }} \text { maka } \mathrm{F}_{\text {hitung }} \\
\text { lebih besar dari } \mathrm{F}_{\text {tabel. Nilai probabilitas }} \\
\text { (sign.) dari hasil analisis adalah } 0,000 \text {. } \\
\text { Nilai probabilitas tersebut lebih kecil } \\
\text { dari pada } 0,05(<0,05) \text { maka } \mathrm{H}_{0} \text { ditolak. } \\
\text { Dengan kata lain terdapat pengaruh } \\
\text { kemandirian pada model pembelajaran }\end{array}$}} \\
\hline \multicolumn{3}{|c|}{$\begin{array}{l}\text { engaruh dari setiap variabel penelitian } \\
\text { elanjutnya akan dilakukan uji hipotesis } \\
\text { lengan menggunakan uji analisis Two } \\
\text { Vay Anova. Adapun hasil pengujiannya } \\
\text { ersaji pada Tabel } 2 \text {. }\end{array}$} & & \\
\hline \multicolumn{3}{|c|}{$\begin{array}{l}\text { Berdasarkan Tabel } 2 \text { dijelaskan } \\
1 \text { uji hipotesis dan keputusan dari } \\
1 \text { analisis tersebut yaitu sebagai } \\
\text { kut: }\end{array}$} & & \\
\hline \multicolumn{3}{|c|}{$\begin{array}{l}\text { Efek faktor model pembelajaran } \\
\text { Co-op Co-op mandiri dan Co-op Co- }\end{array}$} & $\begin{array}{l}\text { dan gaya be } \\
\text { kemampuan } \\
\text { matematika. }\end{array}$ & $\begin{array}{ll}\text { lajar siswa terhadap } \\
\text { pemecahan } & \text { masalah }\end{array}$ \\
\hline
\end{tabular}
op konvensional) dan gaya belajar 
ISSN 2089-8703 (Print) Vol. 7, No. 3 (2018) 482-491

ISSN 2442-5419 (Online)

Tabel 2. Hasil Uji_t

Tests of Between-Subjects Effects

Dependent Variable:kemampuan pemecahan masalah

\begin{tabular}{|c|c|c|c|c|c|}
\hline Source & $\begin{array}{l}\text { Type III Sum of } \\
\text { Squares }\end{array}$ & $\mathrm{df}$ & Mean Square & $\mathrm{F}$ & Sig. \\
\hline Corrected Model & $6626,378^{\mathrm{a}}$ & 5 & 1325,276 & 40,953 &, 000 \\
\hline Intercept & 362415,719 & 1 & 362415,719 & 11199,069 &, 000 \\
\hline Kelas & 215,589 & 2 & 107,795 & 3,331 & 041 \\
\hline gaya_belajar & 5686,353 & 1 & 5686,353 & 175,715 &, 000 \\
\hline kelas * gaya_belajar & 232,427 & 2 & 116,214 & 3,591 & 032 \\
\hline Error & 2718,344 & 84 & 32,361 & & \\
\hline Total & 377345,000 & 90 & & & \\
\hline Corrected Total & 9344,722 & 89 & & & \\
\hline
\end{tabular}

a. R Squared $=, 709$ (Adjusted R Squared $=, 692$ )

\section{Hipotesis 2}

Berdasarkan Tabel 2 terlihat bahwa nilai $F_{\text {hitung }}$ untuk variabel kelas dalam hal ini kelas yang menggunakan model pembelajaran Co-op Co-op mandiri dan Co-op Co-op konvensional sebesar 3,331. Nilai $F_{\text {hitung }}$ tersebut jika dibandingkan dengan nilai $F_{\text {tabel }}$ yaitu 3,10 maka dapat disimpulkan bahwa $\mathrm{F}_{\text {hitung }}>\mathrm{F}_{\text {tabel. }}$. Nilai probabilitas (sign.) dari hasil analisis adalah 0,041. Nilai probabilitas tersebut lebih kecil dari $0,05(<0,05)$ maka $\mathrm{H}_{0}$ ditolak. Dengan kata lain, terdapat pengaruh kemandirian model pembelajaran Co-op Co-op terhadap pemecahan masalah matematika.

\section{Hipotesis 3}

Berdasarkan tabel 2 terlihat bahwa nilai $F_{\text {hitung }}$ untuk variabel gaya belajar siswa (independen dan dependen) sebesar 175,715 . Nilai $F_{\text {hitung }}$ tersebut jika dibandingkan dengan nilai $F_{\text {tabel yaitu 3,10, maka dapat }}$ disimpulkan bahwa $F_{\text {hitung }}<\mathrm{F}_{\text {tabel }}$. Nilai probabilitas (sign.) dari hasil analisis adalah 0,000 . Nilai probabilitas tersebut lebih kecil dari $0,05(<0,05)$ maka $\mathrm{H}_{0}$ ditolak. Dengan kata lain, terdapat pengaruh gaya belajar siswa terhadap pemecahan masalah matematika.

\section{Hipotesis 4}

Efek interaksi factor model pembelajaran dan gaya belajar siswa terhadap pemecahan masalah matematika siswa, dapat dilihat pada $F_{\text {hitung }}$ sebesar 3,591 dengan nilai $F_{\text {tabel }}$ sebesar 3,10. Jika dibandingkan maka nilai $F_{\text {hitung }}>F_{\text {tabel }}$. Nilai probabilitas (sign.) dari hasil analisis sebesar 0,032, jika dibandingkan dengan nilai alpha $(0,05)$ maka nilai probabilitas (sign.) lebih besar dari nilai alpha. Maka dapat disimpulkan bahwa terdapat interaksi antara model pembelajaran Co-op Coop dan gaya belajar siswa dalam mempengaruhi kemampuan pemecahan masalah matematika.

Selanjutnya untuk mengetahui rataan manakah yang membuat kemampuan pemecahan masalah siswa berbeda, dilakukan iju lanjut yaitu multiple comparisons setelah uji anava. Metode yang digunakan untuk uji lanjut adalah uji t,dimana uji ini untuk membandingkan rata-rata grup yang tidak berhubungan satu sama lain, apakah kedua grup tersebut mempunyai rata-rata sama atau tidak. Adapun hasil uji t pada Tabel 3. 
ISSN 2089-8703 (Print) Vol. 7, No. 3 (2018) 482-491

ISSN 2442-5419 (Online)

Tabel 3. Hasil Uji Lanjut Pasca Anava

\section{Multiple Comparisons}

Dependent Variable:kemampuan pemecahan masalah

\begin{tabular}{|c|c|c|c|c|c|c|c|}
\hline \multirow[t]{2}{*}{+2} & \multirow[t]{2}{*}{ (I) kelas } & \multirow[t]{2}{*}{ (J) kelas } & \multirow[b]{2}{*}{$\begin{array}{c}\text { Mean } \\
\text { Difference } \\
(\mathrm{I}-\mathrm{J})\end{array}$} & \multirow[b]{2}{*}{$\begin{array}{l}\text { Std. } \\
\text { Error }\end{array}$} & \multirow[b]{2}{*}{ Sig. } & \multicolumn{2}{|c|}{$\begin{array}{l}95 \% \text { Confidence } \\
\text { Interval }\end{array}$} \\
\hline & & & & & & $\begin{array}{l}\text { Lower } \\
\text { Bound }\end{array}$ & $\begin{array}{l}\text { Upper } \\
\text { Bound }\end{array}$ \\
\hline \multirow{6}{*}{$\begin{array}{l}\text { Tukey } \\
\text { HSD }\end{array}$} & eksperimen 1 & eksperimen2 &,- 67 & 1,469 & ,893 & $-4,17$ & 2,84 \\
\hline & & Kontrol & $5,83^{*}$ & 1,469 &, 000 & 2,33 & 9,34 \\
\hline & eksperimen2 & eksperimen1 & ,67 & 1,469 &, 893 & $-2,84$ & 4,17 \\
\hline & & Kontrol & $6,50^{*}$ & 1,469 &, 000 & 3,00 & 10,00 \\
\hline & Kontrol & eksperimen1 & $-5,83^{*}$ & 1,469 &, 000 & $-9,34$ & $-2,33$ \\
\hline & & eksperimen2 & $-6,50^{*}$ & 1,469 &, 000 & $-10,00$ & $-3,00$ \\
\hline
\end{tabular}

Berdasarkan Tabel 3, dapat dilihat bahwa sign. Pada model pembelajaran Co-op Co-op mandiri kelas eksperimen 1 sebesar 0,893, jika dibandingkan dengan nilai alpha 0,05 maka nilai tersebut lebih besar dari nilai alpha. Sedangkan model pembelajaran Co-op Co-op mandiri pada kelas eksperimen 2 diperoleh nilai sign. 0,893 jika dibandingkan dengan nilai alpha 0,05 maka nilai tersebut lebih besar dari nilai alpha.

Bisa dikatakan sign. Model pembelajaran Co-op Co-op pada kelas eksperimen 1 dan kelas eksperimen 2 sama. Pada kelas kontrol yang menggunakan model pembelajaran coopco-op konvensional diperoleh nilai sign. Sebesar 0,000, dibandingkan dengan nilai sign. Alpha maka nilai sign. Lebih kecil dari Alpha. Maka dapat disimpulkan bahwa tidak ada perbedaan rata-rata kemampuan pemecahan masalah siswa antar kelas eksperimen 1 dan eksperimen 2. Namun terdapat perbedaan rata-rata antara kelas eksperimen 1 terhadap kelas kontrol dan kelas eksperimen 2 terhadap kelas kontrol.

Temuan ini didukung oleh hasil temuan Ferinaldi (2013) yang mengatakan bahwa model pembelajaran Co-op Co-op berpengaruh terhadap pemecahan masalah dan penalaran matematis mahasiswa. Model kooperatif tipe Co-op Co-op juga menjadi inovasi agar siswa lebih aktif lagi belajar. Hal ini dapat menyebabkan proses pembelajaran lebih menyenangkan dan menarik.

Dengan menggunakan model pembelajaran Co-op Co-op, siswa menjadi terlibat dan aktif dalam proses pembelajaran, selain itu juga siswa bertanggung jawab terhadap tugas yang diberikan kepadanya. Model pembelajaran Co-op Co-op merupakan model pembelajaran kooperatif yang berorientasi pada tugas pembelajaran dan peserta didik mengendalikan apa dan bagaimana mempelajari bahan yang ditugaskan kepada mereka. 
Metode ini menempatkan tim dalam koperasi antara satu dengan lainnya untuk mempelajari sebuah topik di kelas. Co-op Co-op memberi kesempatan pada peserta didik untuk bekerja sama dalam kelompokkelompok kecil, pertama untuk meningkatkan pemahaman mereka tentang diri mereka dan dunia, dan selanjutnya memberikan mereka kesempatan untuk saling berbagi pemahaman baru itu dengan temanteman sekelasnya (Slavin, 2005:229).

Maka dengan adanya spesialisasi tugas ini dapat membuat semua anggota kelompok bekerja dan tidak ada yang hanya duduk diam dan menunggu hasil. Dibandingkan dengan tipe yang lain tipe ini merupakan pembelajaran dengan spesialisasi tugas individu bukan hanya tugas kelompok. Spesialisasi tugas ini dapat menyelesaikan masalah tanggung jawab individual dengan membuat setiap siswa memiliki tanggung jawab khusus terhadap kontribusinya sendiri pada kelompok.

Tugas ini akan membuat siswa merasa bangga karena telah memberikan kontribusinya terhadap kelompok. Tugas kelompok mempunyai sifat saling terkait satu sama lain oleh penggunaan sistem skor kelompok (Slavin, 2005:213-214)

\section{KESIMPULAN DAN SARAN}

Berdasarkan hasil penelitian yang telah dilaksanakan, dapat disimpulkan bahwa (1) terdapat pengaruh model pembelajaran kooperatif tipe Co-op Co-op mandiri dan gaya belajar terhadap kemampuan pemecahan masalah siswa kelas $\mathrm{X}$ SMAN, (2) terdapat pengaruh model pembelajaran kooperatif tipe Co-op Coop mandiri terhadap kemampuan pemecahan masalah siswa kelas $\mathrm{X}$ SMAN, (3) terdapat pengaruh gaya belajar terhadap kemampuan pemecahan masalah siswa kelas $\mathrm{X}$ SMAN dan (4) terdapat interaksi antara model pembelajaran kooperatif tipe $\mathrm{Co}$ op Co-op dan gaya belajar dalam mempengaruhi kemampuan pemecahan masalah trigonometri siswa kelas $\mathrm{X}$ SMAN.

Adapun saran-saran yang disampaikan sehubungan dengan hasil penelitian adalah (1) Guru dapat menjadikan model pembelajaran Co-op Co-op mandiri sebagai alternatif penyelenggaraan pembelajaran karena terbukti bahwa model pembelajaran $\mathrm{Co}$ op Co-op mandiri berpengaruh terhadap hasil pemecahan masalah baik bagi siswa yang memiliki gaya belajar dependen dan gaya belajar independen, (2) Dalam memilih model pembelajaran seorang guru mempertimbangkan tujuan pembelajaran yang akan dicapai , sumber-sumber belajar yang relevan dengan model pembelajaran tersebut dan gaya belajar siswa, (3) Bagi guru yang ingin menggunakan model Co-op Co-op mandiri disarankan untuk terlebih dahulu mempelajari dan merancang rencana dan mempertimbangkan estimasi penggunaan waktu ketika mengajar (4) Guru sebaiknya mengenali gaya belajar masing-masing siswa agar dapat membantu siswa dalam kegiatan belajarnya secara efektif dan efisien dan (5) Bagi peneliti lain yang ingin melakukan penelitian lanjutan yang serupa, dapat mengujicoba model pembelajaran Co-op Co-op mandiri pada mata pelajaran lainnya.

\section{DAFTAR PUSTAKA}

Dewi., Sugiarti,, T., \& Suharto. (2013). Penerapan Model Cooperative Tipe Co-op Co-op disertai Metode Eksperimen untuk Meningkatkan Aktifitas dan Hasil 
Belajar Siswa kelas VIII pada materi pythagoras di SMP Negeri 2 Rambipuji. Jurnal Kadikma 4(3), 33-42.

Deporter, B \& Mike, H. (2010). Quantum Learning. Bandung. Kaifa

Dimyati \& Mudjiono. (2013). Belajar dan Pembelajaran. Jakarta: Rineka Cipta

Ferinaldi. (2013). Pengaruh Penerapan Model Pembelajaran Co-op Co-op Terhadap Pemecahan Masalah Dan Penalaran Matematis Mahasiswa Pendidikan Matematika Jurnal Pendidikan STKIP YPM Bangko, 1(1). Universitas Negeri Padang.

Kurniawan, W. dkk. (2015). Eksperimentasi Model Pembelajaran Co-op Co-op, Discovey Learning Dan Problem Based Dengan Pendekatan Saintifik Siswa Kelas VIII SMP Negeri Sekabupaten Ngawi Pada Materi Bangun Ruang Sisi Datar Ditinjau Dari Kreativitas Belajar Matematika. Jurnal Pembelajaran Matematika 3(8), 868-881. Universitas Sebelas Maret Surakarta

Mahuda, I. (2017). Pembelajaran Kooperatif Co-op Co-op Dengan Pendekatan Open-Ended Untuk Meningkatkan Kemampuan Pemecahan Masalah Matematis Siswa SMA. Jurnal Penelitian dan Pembelajaran Matematika Untirta, 10(2), 31-39.

National Council of Teacher of Mathematics. (2000). Principles and Standards for School Mathematics. Reston, VA: NCTM

Nur \& Rini. (2013). Gaya Belajar: Kajian Teoritik. Yoyakarta: Pustaka Pelajar.
Slavin, R. E. (2005). Cooperative Learning: Teori Riset dan Praktik. Terjemahan Lita. Bandung: Nusa Media.

Sugiyono. (2010). Metode Penelitian Pendidikan Pendekatan Kuantitatif, Kualitatif dan $R \& D$. Bandung:Alfabeta

Thamimi, M. \& Kusnoto, Y. (2017). Penerapan Model Pembelajaran Kooperatif Tipe Co-Op Co-Op Terhadap Kemampuan Mengidentifikasi Unsur Intrinsik Cerpen Siswa Kelas X. Jurnal Edukasi 15(2), 253-260.

Yusuf, H. (2014). Matematika: Strategi Pemecahan Masalah. Yogyakarta: Graha Ilmu. 